\title{
Physical Bioassay Object
}

National Cancer Institute

\section{Source}

National Cancer Institute. Physical Bioassay Object. NCI Thesaurus. Code C44181.

A bioAssay created by the bioAssayCreation event (e.g. in gene expression analysis this event is represented by the hybridization event). 